\title{
Radiological Risks from Natural Radionuclides in Surface Soil of Agbara Industrial Area, Ogun State, Nigeria
}

\author{
ADEMOLA, AK \\ Department of Physical Sciences, Bells University of Technology, Ota, Ogun State. Nigeria \\ Corresponding Author Email: drakademola@yahoo.com; Tel: +234 7031921302; +23459000640
}

\begin{abstract}
Measurement of natural radioactivity in soil samples from the Agbara Industrial area, Nigeria, was measured using gamma-ray spectrometry with $\mathrm{NaI}(\mathrm{Tl})$ detector. The concentration of ${ }^{238} \mathrm{U}$ ranged from $10.21 \pm 3.50$ to 67.41 $\pm 18.2 \mathrm{Bqkg}^{-1}$, from $26.43 \pm 10.8$ to $96.24 \pm 18.81$ for ${ }^{232} \mathrm{Th}$ and from $298.65 \pm 60.70$ to $840.52 \pm 150.25 \mathrm{Bqkg}^{-1}$ for ${ }^{40} \mathrm{~K}$. Their means were, respectively, $28.69 \pm 11.00,45.86 \pm 10.25$, and $481.22 \pm 106.17 \mathrm{Bqkg}^{-1}$. Annual effective varies from 0.08 to $0.16 \mathrm{mSv} \mathrm{y}^{-1}$ with a mean of $0.11 \mathrm{mSv} \mathrm{y}^{-1}$. The mean contamination factor was 0.87 for ${ }^{228} \mathrm{Ra}, 1.02$ for ${ }^{232} \mathrm{Th}$ and, 1.15 for ${ }^{40} \mathrm{~K}$.The soil is moderately polluted with ${ }^{232} \mathrm{Th}$ and ${ }^{40} \mathrm{~K}$. The Pollution Level Index indicates a drop in soil quality in about $50 \%$ of the areas covered. The mean cancer risk $\left(0.4 \times 10^{-3}\right)$ obtained in this study is above the World Health Organization limit, indicating a high probability for inhabitants to develop lung cancer in the long term when a lifetime is spent in this area under study.
\end{abstract}

\section{DOI:https://dx.doi.org/10.4314/jasem.v25i5.7}

Copyright: Copyright $(0) 2021$ Ademola. This is an open access article distributed under the Creative Commons Attribution License (CCL), which permits unrestricted use, distribution, and reproduction in any medium, provided the original work is properly cited.

Dates: Received: 20 March 2021; Revised: 27 April 2021; Accepted: 07 May 2021

Keywords: Radiological risk, radionuclide, cancer risk, pollution index

Natural radionuclide has been present since the existence of the earth. So Man is continuously exposed to natural radioactivity everywhere on the earth's surface. About eighty per cent of the radiation a human received per year is due to natural background gamma radiation and received about $2.4 \mathrm{mSv}$ of natural radiation in a year (IAEA 1996). The level of natural radioactivity of an area depends on its geology, rocks, and soil types (Tzortzis et al., 2004). The sources of natural radiation are ${ }^{40} \mathrm{~K},{ }^{238} \mathrm{U},{ }^{232} \mathrm{Th}$, and their progeny found in the ground (Al-Jundi et al., 2003). Urbanization, mining activities, waste disposal systems, and several human activities are contributors to the radioactivity of the environment (UNSCEAR, 2000). Many industries discharge untreated wastes (wastewater, effluent, sludge) into their vicinity, which may contain an elevated concentration of radionuclides due to the technological processes involved in some productions in some of these industries. High levels of NORM are well-known in major industrial areas (Faisal et al., 2014 in Savar industrial area, Bangladesh; Attia et al., (2015) in Port Said Egypt; Zaim et al., (2016) in Turkey; Ugbede and Benson(2018) in Nigeria and Shen et al., 2019 in general industrial waste in Guizhou, China). Radioactivity in soils is gaining considerable interest from researchers both in Nigeria and abroad because it estimates public doses and predicts changes caused by radionuclides in the environment (UNSCEAR, 2000).
Hence, the growing concern about the quality of the environment needs a quality impact assessment of radioactivity of the environment to predict radioactive damage done by the industries. The study aimed to measure natural radioactivity in soil samples from the Agbara Industrial area, Nigeria. The results obtained will be used to estimate the radiological hazards and pollution level index.

\section{MATERIALS AND METHODS}

Study Area: Agbara industrial area is positioned within longitude $2.82 \mathrm{o}$ and $3.09 \mathrm{o}$ E, latitude $6.50 \mathrm{o}$ and $7.92 \mathrm{o}$ N.

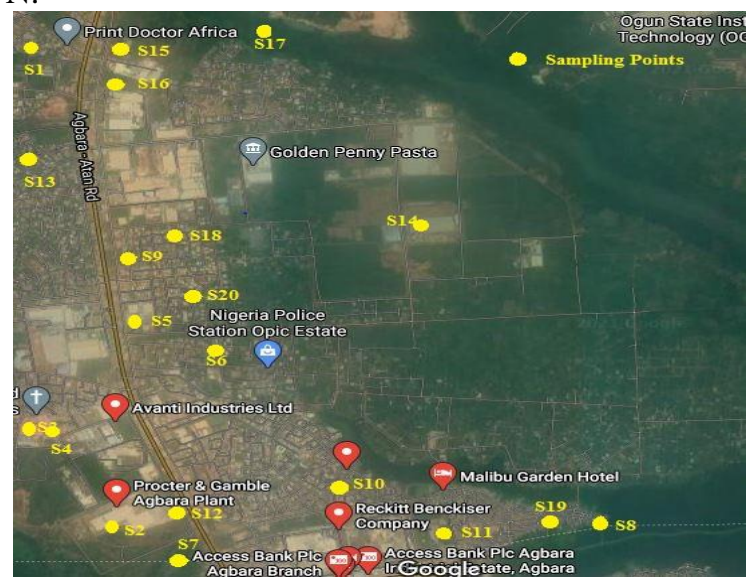

Fig 1: Geo-satellite map of Agbara Industrial Area showing the sampling points 
It is situated about $30 \mathrm{~km}$ away from Lagos along the Lagos-Badagry expressway in Ogun State, Nigeria. The altitude is about 37 asl (Ojekunle et al., 2018) (Figure 1). Agbara is known for industrial activities. Many industries are domicile in the area ranging from milling, pharmaceuticals and chemicals, processing, and manufacturing industries like (building materials, e.g. tiles, aluminum companies, beverages, pampers, etc.)

Collection of samples and preparation for analysis: Sixty (60) samples; four (4) each from twenty locations in Agbara industrial areas were randomly collected. The samples were collected $15-20 \mathrm{~cm}$ deep at each location. The samples were collected $15-20 \mathrm{~cm}$ deep at each location. All the samples were individually parked into a polythene bag, labeled, and spread on a tray for 3days to dry at room temperature. They were processed using a standard procedure that is irrelevant materials such as stones, roots, gravel, etc, were removed, and the samples were well mixed afterward. The samples were crushed into powder and sieved through a $2 \mathrm{~mm}$ sieve. A $200 \mathrm{~g}$ of the sieved samples were placed into the plastic container and sealed for a month for secular equilibrium before measurement (Sathyapriva et al., 2017). Table 1shows the sampling locations and their coordinates.

Table 1: sampling location and their coordinates in Agbara area

\begin{tabular}{|c|c|c|c|}
\hline $\begin{array}{l}\text { Sampling Point } \\
\text { Sample ID }\end{array}$ & Location & $\begin{array}{l}\text { Latitude } \\
\mathrm{N}^{\circ}\end{array}$ & $\begin{array}{l}\text { Longitudes } \\
\mathrm{E}^{\mathrm{o}}\end{array}$ \\
\hline S1 & Ketu Adie-Owe (Momo Agent area) & $06^{\circ} 35^{\prime} 12.13^{\prime \prime}$ & $003^{\circ} 04 ` 55.2^{\prime \prime}$ \\
\hline S2 & Big Cola plant & $06^{\circ} 30^{\prime} 22.32^{\prime \prime}$ & $003^{\circ} 04^{`} 30.0^{\prime \prime}$ \\
\hline S3 & Servico area (Phase 3 ) & $06^{\circ} 30^{\circ} 43.92^{\prime \prime}$ & $003^{\circ} 04^{\prime} 18.84^{\prime \prime}$ \\
\hline S4 & Drury Industrial area & $06^{\circ} 30^{\prime} 37.08^{\prime \prime}$ & $003^{\circ} 04^{`} 19.99^{\prime \prime}$ \\
\hline S5 & Opic Estate (Petedo area) & $06^{\circ} 30^{\prime} 50.94^{\prime \prime}$ & $003^{\circ} 04^{\prime} 19.45^{\prime \prime}$ \\
\hline S6 & Opic (NPF Station Area) & $06^{\circ} 31^{\prime} 8.7^{\prime \prime}$ & $003^{\circ} 05^{`} 12.7^{\prime}$ \\
\hline S7 & Access Bank Area & $06^{\circ} 30^{\prime} 2.2^{\prime \prime}$ & $003^{\circ} 05^{\prime} 36.64^{\prime \prime}$ \\
\hline S8 & Overcomer N/P School area & $06^{\circ} 30^{\circ} 23.27^{\prime \prime}$ & $003^{\circ} 05^{`} 50.86^{\prime \prime}$ \\
\hline S9 & Nestle Factory area & $06^{\circ} 30^{\prime} 6.84^{\prime \prime}$ & $00305^{`} 16.84^{\prime \prime}$ \\
\hline S10 & Corona Sec Sch. Area & $06^{\circ} 30^{\prime} 37.44^{\prime \prime}$ & $003^{\circ} 05^{\prime} 17.41^{\prime \prime}$ \\
\hline S11 & Reckitt Company area & $06^{\circ} 30^{`} 19.87^{\prime}$ & $003^{\circ} 05^{\prime} 30.3^{\prime \prime}$ \\
\hline S12 & Procter and Gamble plant area & $06^{\circ} 32^{\prime} 34 . .80^{\prime \prime}$ & $003^{\circ} 04^{\prime} 37.7^{\cdots}$ \\
\hline S13 & Omoshola Phase 2 (Ologbo Eremi & $06^{\circ} 32^{`} 0.42^{\prime \prime}$ & $00.3^{\circ} 02^{`} 1.86^{\prime \prime}$ \\
\hline S14 & Beta Glass area & $06^{\circ} 30^{\prime} 11.02^{\prime \prime}$ & $003^{\circ} 05^{\prime} 39.16^{\prime \prime}$ \\
\hline S15 & Print Color Africa Area & $06^{\circ} 32^{\prime} 51.02^{\prime \prime}$ & $003^{\circ} 04^{\prime} 26.65^{\prime \prime}$ \\
\hline S16 & Crown City Resorts and Hotel area & $06^{\circ} 32^{\prime} 37.64^{\prime \prime}$ & $003^{\circ} 04^{`} 24.64^{\prime \prime}$ \\
\hline S17 & Access Closa Agent Area & $06^{\circ} 32^{`} 49.42^{\prime \prime}$ & $003^{\circ} 0427.59^{\prime \prime}$ \\
\hline S18 & Firstmonie Agent area & $06^{\circ} 32^{\prime} 45.02^{\prime \prime}$ & $003^{\circ} 04^{\prime} 34.19^{\prime \prime}$ \\
\hline S19 & Beloxxi Group Industries area & $07^{\circ} 54^{\prime} 56.39^{\prime \prime}$ & $002^{\circ} 49^{\prime} 37,2^{\prime \prime}$ \\
\hline S20 & Primera food & $06^{\circ} 32^{\prime} 21.84^{\prime \prime}$ & $003^{\circ} 02^{`} 16.87^{\prime \prime}$ \\
\hline
\end{tabular}

Activity determination analysis: A Sodium Iodide NaI (Tl) detector was used to measure radionuclides in the samples. A scintillation detector and a Canberra multichannel analyzer were set up for the counting. A $7.6 \mathrm{x}$ $7.6 \mathrm{cmcm} 2 \mathrm{NaI}(\mathrm{Tl})$ manufactured by Bicron Electronics Ltd, USA with model no. 8020 was used and connected to the multi-channel analyzer with a coaxial cable. The detector is shielded by a cylindrical lead of $5 \mathrm{~cm}$ thick at the bottom and at the top to shield against background radiation. The calibration for efficiency detection was performed with a standard reference gamma source supplied by Rocketdyne Laboratories, Canoga Park, CA, USA. The resolution of the detector assembly is $\sim 8 \%$ at $0.662 \mathrm{MeV}$ of $137 \mathrm{Cs}$. The energy calibration was performed with gamma sources from the IAEA, Vienna. The energychannel calibration obtained was fit linearly, and the equation was stored in the memory of the analyzer to measure the activities of the radionuclides. The count of an empty container was taken as background count and was removed from the gross count to get the net count. The counting time was $10 \mathrm{~h}$. The concentration of radionuclides in the samples was determined using1.764 MeV gamma-rays from 214Bi for226Ra, gamma-ray energy of $2.614 \mathrm{MeV}$ from $208 \mathrm{Tl}$ for the activity of $232 \mathrm{Th}$, and gamma-ray of $1.460 \mathrm{MeV}$ from $40 \mathrm{~K}$ for the $40 \mathrm{~K}$ activity. A software (Genie $2 \mathrm{~K}$ ), spectrum acquisition and analysis software manufactured by Canberra Industries Inc. USA) was used to analyze the activity of radionuclides.

Determination of radiological hazards: Absorbed dose: The absorbed dose rate (Do) in the air at the height of $1 \mathrm{~m}$ above the ground was estimated from the concentrations of ${ }^{238} \mathrm{U},{ }^{232} \mathrm{Th}$, and ${ }^{40} \mathrm{~K}$ as described in equation 1 given by UNSCEAR, 2000.

$$
D o=0.428 C_{R a}+0.632 C_{T h}+0.044 C_{K}
$$

Where $\mathrm{C}_{\mathrm{Ra}}, \mathrm{C}_{\mathrm{Th}}$, and $\mathrm{C}_{\mathrm{K}}$ are the activity concentrations of ${ }^{226} \mathrm{Ra},{ }^{232} \mathrm{Th}$, and ${ }^{40} \mathrm{~K}$. 
Effective Dose (ED): The annual effective dose (ED) was calculated using equation 2 . This equation converts the absorbed dose rate to effective dose using $0.7 \mathrm{SvGy}^{-1}$ and considers the outdoor occupancy factor, i.e. the average time spent outdoors by people. On average, inhabitants spent 7-8hours a day outdoor, meaning that about $30 \%$ of the 365 days in a year (Cevik et al., 2008).

$$
\begin{aligned}
& E D(\mu S v)=D_{0}\left(n G y h^{-1}\right) \times 8760\left(h y^{-1}\right) \times \\
& 0.7\left(S v G y^{-1}\right) \times 10^{-6} \times 0.3
\end{aligned}
$$

Where $\mathrm{D}_{0}$ is the absorbed dose $\left(\mathrm{nGyh}^{-1}\right) ; 8760$ is the hours in a year; 0.3 is the outdoor occupancy factor; $0.7 \mathrm{SvGy}^{-1}$ is the conversion factor from $\mathrm{D}_{0}$ to $\mathrm{ED}$ and $10^{-6}$ converts nano into milli.

Radium Equivalent $\left(R a_{e q}\right)$ : This is a quantity that is commonly used to identify the uniformity of radiation exposure i.e. the activity concentration of a radionuclide equivalent to $370 \mathrm{~Bq}$ $\mathrm{kg}^{-1}$ of ${ }^{226} \mathrm{Ra}$. The quantity $\mathrm{Ra}_{\mathrm{eq}}$ was calculated using equation 3 UNSCEAR, (2000)

$$
R a_{e q}=C_{R a}+1.43 C_{T h}+0.077 C_{K}
$$

Where $\mathrm{Ra}$ is the radium equivalent activity; $\mathrm{C}_{\mathrm{Ra}}, \mathrm{C}_{\mathrm{Th}}$, and $\mathrm{C}_{\mathrm{K}}$ denote ${ }^{226} \mathrm{Ra},{ }^{232} \mathrm{Th}$, and ${ }^{40} \mathrm{~K}$, respectively.

External Hazard Index $\left(H_{e x}\right)$ : Parts of the area under study are used to cultivate crops, especially vegetables, and to fill in the construction of houses. The soil samples may contain an elevated concentration of natural radionuclides, which may add to the external gamma dose rates the inhabitants receive. To reduce dose the inhabitants from the usage of soil in dwelling construction, $\mathrm{H}_{\mathrm{ex}}$ was calculated from equation 4(El-Taher, (2010)

$$
H_{e x}=\frac{C_{R a}}{370}+\frac{C_{T h}}{259}+\frac{C_{K}}{4810} \leq 1
$$

Where Hex is the external hazard index, $\mathrm{C}_{\mathrm{Ra}}, \mathrm{C}_{\mathrm{Th}}$, and $\mathrm{C}_{\mathrm{K}}$ denote the usual meaning.

Internal Hazard Index $\left(H_{\text {in }}\right)$ : Radon and its short-lived products are products of the uranium series and are hazardous to the respiratory system. Internal exposure to radon and its short-lived products from the soil termed internal hazard index $\left(\mathrm{H}_{\mathrm{in}}\right)$ was calculated using equation 5 given by (UNSCEAR, 2000)
$H_{\text {in }}=\frac{C_{R a}}{185}+\frac{C_{T h}}{259}+\frac{C_{K}}{4810} \leq 1$

Through the inhalations of dust particles, the inhabitants are exposed to radioactive materials from the dust. Through inhalation of contaminated dust, the inhabitants are liable to develop lung cancer. Therefore, the probability of developing lung cancer (Cancer Risk) (CR) was estimated per million of the inhabitants, using equation 6given by ICRP, (2007).

$$
E L C R=E D \times L_{E} \times C_{F}
$$

Where CR is the Cancer Risk, ED, the effective dose, $\mathrm{L}_{\mathrm{E}}$ is life expectancy (70 years) and $\mathrm{C}_{\mathrm{F}}$ is the risk factor given as $0.05 \mathrm{~Sv}^{-1}$ (ICRP, 1991).

\section{RESULTS AND DISCUSSION}

The concentrations of ${ }^{238} \mathrm{U},{ }^{232} \mathrm{Th}$, and ${ }^{40} \mathrm{~K}$ are presented in Table 2. The minimum concentration of ${ }^{238} \mathrm{U}(10.21 \pm 3.50)$ was obtained in $\mathrm{S} 6$, while the maximum was obtained from S3 $(67.41 \pm 18.2)$. The mean of ${ }^{226} \mathrm{Ra}$ was $28.69 \pm 11.00 \mathrm{Bqkg}^{-1}$. Although the mean value is below the UNSCEAR recommendation, about $35 \%$ of the samples have radium concentration above the world average (UNSCEAR, 2008).Also, about $55 \%$ of the samples have concentrations above the world average of 45 Bqkg-1 (UNSCEAR, 2008) for ${ }^{232} \mathrm{Th}$. The minimum concentration was from $\mathrm{S} 1$ $(26.43 \pm 10.8)$, while the maximum was from S7 $(96.24 \pm 18.81)$ with a mean of $45.86 \pm 10.25 \mathrm{Bqkg}^{-1}$. The maximum concentration of ${ }^{40} \mathrm{~K}$ was obtained in S7 $\left(840.52 \pm 150.25 \mathrm{Bqkg}^{-1}\right)$, while the minimum was from S14 (298.65 \pm 60.70$)$. About $65 \%$ of the samples have concentrations above the world average. The mean concentration of ${ }^{40} \mathrm{~K}$ was $481.22 \pm 106.17 \mathrm{Bqkg}^{-1}$. The radionuclide concentrations are in the order ${ }^{238} \mathrm{U}$ $<{ }^{232} \mathrm{Th}<{ }^{40} \mathrm{~K}$, which implies that the soil samples analyzed are rich in $40 \mathrm{~K}$. Although the results of this study are not sufficiently higher than UNSCEAR recommendations, it should be noted that overexposure to the high concentration of these radionuclides may cause some health issues like lung cancer and other related health challenges (ATSDR, 2014).The results of this study were compared with similar researches locally and internationally in Table 3. The mean of ${ }^{226} \mathrm{Ra}$ obtained in this study (28.69 $\mathrm{Bqkg}^{-1}$ ) is slightly higher than what was obtained in similar researches in Bangladesh, India, and Greece (Faisal et al., 2014, Senthikumar and Narayanaswamy, 2016, Ioannides et al., (1997) but lower than results from Pakistan, Malaysia and Algeria (Tufail et al., 2016; UNSCEAR, 2000; Boukhenfouf et al., 2011). A higher result of ${ }^{232} \mathrm{Th}$ than what was obtained in this study was recorded in some studies from Pakistan, 
Malaysia, Algeria, and Greece as shown in Table 2. The concentration of ${ }^{40} \mathrm{~K}$ was highest in all the sites and the comparison of the results with other studies confirmed this. The mean of this study is lower than what was obtained by a study in India (Narayanaswamy, 2016) and Pakistan (Tufail et al., 2016) but higher than the result of Senthikumar and Narayanaswamy, (2016) in India and Ioannides et al, (1997) in Greece. In Nigeria, the result obtained by
Gbadamosi et al, 2018 in Agbara industrial area revealed a higher concentration of ${ }^{226} \mathrm{Ra}$ than the present study, while lower concentrations of ${ }^{232} \mathrm{Th}$ and ${ }^{40} \mathrm{~K}$ were recorded in their study. Also, these results are lower than results obtained in Port-Harcourt by (Avwiri and Olatunbosun, 2014). The ${ }^{226} \mathrm{Ra}$ result obtained in this study is lower than the result obtained in Lagos (Oladapo et al., 2012) but higher results were obtained for ${ }^{232} \mathrm{Th}$ and ${ }^{40} \mathrm{~K}$ in the present study

\begin{tabular}{llll}
\multicolumn{5}{c}{ Table 2: The concentrations of ${ }^{238} \mathrm{U},{ }^{232} \mathrm{Th}$, and ${ }^{40} \mathrm{~K}$ in the soil samples } \\
\hline Sample ID & ${ }^{226} \mathrm{Ra}$ & ${ }^{232} \mathrm{Th}$ & ${ }^{40} \mathrm{~K}$ \\
\hline S1 & $33.61 \pm 6.10$ & $49.22 \pm 12.01$ & $600.12 \pm 60.45$ \\
S2 & $14.50 \pm 5.81$ & $34.67 \pm 10.8$ & $650.80 \pm 75.31$ \\
S3 & $47.81 \pm 10.2$ & $65.61 \pm 17.2$ & $680.50 \pm 76.10$ \\
S4 & $20.45 \pm 7.21$ & $41.20 \pm 13.22$ & $582.40 \pm 65.30$ \\
S5 & $28.60 \pm 8.50$ & $46.21 \pm 10.62$ & $448.50 \pm 55.31$ \\
S6 & $12.61 \pm 7.80$ & $48.16 \pm 15.00$ & $620.11 \pm 81.15$ \\
S7 & $46.22 \pm 8.81$ & $66.91 \pm 12,21$ & $480.28 \pm 55.42$ \\
S8 & $35.66 \pm 8.11$ & $52.78 \pm 15.21$ & $391.60 \pm 95.01$ \\
S9 & $15.00 \pm 6.53$ & $36.28 \pm 10.41$ & $490.66 \pm 60.31$ \\
S10 & $18.65 \pm 9.24$ & $40.81 \pm 9.81$ & $380.48 \pm 59.00$ \\
S11 & $31.10 \pm 8.62$ & $61.65 \pm 16.70$ & $524.30 \pm 56.32$ \\
S12 & $34.56 \pm 12.90$ & $45.45 \pm 13.51$ & $430.42 \pm 75.31$ \\
S13 & $44.65 \pm 14.87$ & $36.22 \pm 11.51$ & $330.39 \pm 99.61$ \\
S14 & $22.13 \pm 8.92$ & $58.29 \pm 11.85$ & $580.70 \pm 55.62$ \\
S15 & $38.62 \pm 7.88$ & $40.43 \pm 8.20$ & $460.10 \pm 72.80$ \\
S16 & $35.32 \pm 9.46$ & $43.51 \pm 8.98$ & $436.67 \pm 90.34$ \\
S17 & $30.41 \pm 7.92$ & $38.62 \pm 6.52$ & $320.82 \pm 50.31$ \\
S18 & $15.19 \pm 6.80$ & $40.10 \pm 11.21$ & $404.48 \pm 66.22$ \\
S19 & $20.12 \pm 8.10$ & $36.20 \pm 9.80$ & $398.61 \pm 78.21$ \\
S20 & $28.63 \pm 6.28$ & $34.81 \pm 10.2$ & $412.51 \pm 64.24$ \\
\hline Mean & $28.69 \pm 11.00$ & $45.86 \pm 10.25$ & $481.22 \pm 106.17$
\end{tabular}

Table 3: Comparison of result with other similar work in the literature

\begin{tabular}{llllll}
\hline $\mathrm{S} / \mathrm{N}$ & ${ }^{216} \mathrm{Ra}$ & ${ }^{215} \mathrm{Th}$ & ${ }^{46} \mathrm{~K}$ & Country/Region & References \\
\hline 1 & 23.81 & 42.24 & 733.19 & Bangladesh & Faigal et al, 2014 \\
2 & 22.80 & 39.9 & 171.22 & India & Senthilkumar and Narayanaswamy, 2016 \\
3 & 30 & 56 & 602 & Pakistan & Tufail et al, 2016 \\
4 & 66 & 82 & 310 & Malaysia & UNSCEAR, 2000 \\
5 & 53.2 & 50.03 & 311 & Algeria & Boukhenfouf and Boucenna et al., 2011 \\
6 & 16 & 55 & 305 & Greece & Ioannides et al., 1997 \\
7 & 42.95 & 26.84 & 111.05 & Nigeria (Agbara) & Gbadamosi et al., 2018 \\
8 & 3.0 & 3.30 & 122.10 & Nigeria (Sango-Ota) & Ademola et al., 2014 \\
9 & 41.96 & 62.61 & 643 & Nigeria(Port-Harcourt) & Avwiri and Olatumbosun, 2014 \\
10 & 69.19 & 14.49 & 409.44 & Lagos & Oladapo et al., 2012 \\
\hline
\end{tabular}

Table 4 depicts absorbed dose, annual effective dose, radium equivalent dose, external hazard index, internal hazard index, gamma index, and excess lifetime cancer risk results. Absorbed dose rate (D) ranged from $48.28 \mathrm{nGyh}^{-1}$ to $90.55 \mathrm{nGy}$ with a mean of $61.51 \mathrm{nGyh}^{-1}$ (Column 2, Table 4). This value is higher than the recommended value of $59 \mathrm{nGy} \mathrm{h}^{-}$ ${ }^{1}$ (UNSCEAR, 2000). The annual effective dose as presented in Column 3, Table 4 ranged from 0.08 to $0.16 \mathrm{mSvy}^{-1}$ with an average of $0.11 \mathrm{mSv}^{-1}$. The mean values were above the recommended value of 0.07 $\mathrm{mSvy}^{-1}$ in all the sites (UNCSEAR, (2000). The mean value of $\mathrm{Ra}_{\mathrm{eq}}\left(131.32 \mathrm{Bqkg}^{-1}\right)$ is less than the recommended value of $370 \mathrm{~Bq} \mathrm{~kg}^{-1}$ (UNSCEAR, 1982) and is presented, in column 4.The external hazard index, internal hazard index, and gamma index are presented in columns 5, 6, and 7 in Table 4. The mean values obtained were $0.35,0.43$, and 0.49 , respectively. These values are lower than unity, indicating that the samples are non-hazardous to be used to construct dwellings. The cancer risk (CR) for the habitants of the area through inhalation of contaminated dust was estimated and presented in column 8 of Table 4 . The mean CR in the study area was $0.4 \times 10^{-3}$ which, is higher the range recommended by USEPA $\left(1.0 \times 10^{-6}-1.0 \times 10^{-4}\right)$ (USEPA, 2003). This higher value indicates high probability of developing cancer in the long term when a lifetime is spent in this area. 
Table 4: The absorbed Dose (D), Effective Dose (ED) and External (Hex) and Internal Hazard Index $\left(\mathrm{H}_{\text {in }}\right)$, Radium Equivalent Dose (Ra ${ }_{\mathrm{eq}}$ ), Gamma Index $\left(\begin{array}{l}\mathrm{I} \\ \mathrm{y}\end{array}\right)$ and Excess Lifetime Cancer Risk (ELCR) of all topsoil samples

\begin{tabular}{llllllll}
\hline Sample ID & $\begin{array}{c}\text { Absorbed dose } \\
(\mathrm{D})\left(\mathrm{nGyh}^{-1}\right)\end{array}$ & $\begin{array}{l}\text { Effective } \\
\text { Dose(ED) } \\
(\mathrm{mSvy})\end{array}$ & $\begin{array}{l}\left.\mathrm{Ra}_{\mathrm{eq}}\right) \\
\left(\mathrm{Bqkg}^{-1}\right)\end{array}$ & $\mathrm{H}_{\mathrm{ex}}$ & $\mathrm{H}_{\mathrm{in}}$ & $\mathrm{I}_{y^{\prime}}$ & $\begin{array}{l}\text { ELCR } \\
\text { x } 10^{-3}\end{array}$ \\
\hline S1 & 70.82 & 0.13 & 150.20 & 0.40 & 0.50 & 0.56 & 0.46 \\
S2 & 55.78 & 0.10 & 114.19 & 0.31 & 0.35 & 0.44 & 0.36 \\
S3 & 90.55 & 0.16 & 194.03 & 0.52 & 0.65 & 0.71 & 0.58 \\
S4 & 59.44 & 0.11 & 124.21 & 0.33 & 0.39 & 0.47 & 0.38 \\
S5 & 60.28 & 0.11 & 129.21 & 0.35 & 0.43 & 0.48 & 0.39 \\
S6 & 62.05 & 0.11 & 129.23 & 0.35 & 0.38 & 0.49 & 0.40 \\
S7 & 82.07 & 0.15 & 178.88 & 0.48 & 0.61 & 0.65 & 0.53 \\
S8 & 64.95 & 0.12 & 141.29 & 0.38 & 0.48 & 0.51 & 0.42 \\
S9 & 50.11 & 0.09 & 104.66 & 0.28 & 0.32 & 0.39 & 0.32 \\
S10 & 49.75 & 0.09 & 106.31 & 0.29 & 0.34 & 0.39 & 0.32 \\
S11 & 74.23 & 0.14 & 159.63 & 0.43 & 0.51 & 0.59 & 0.48 \\
S12 & 61.58 & 0.11 & 132.69 & 0.36 & 0.45 & 0.49 & 0.40 \\
S13 & 55.84 & 0.10 & 121.88 & 0.33 & 0.45 & 0.44 & 0.36 \\
S14 & 70.73 & 0.13 & 150.19 & 0.41 & 0.47 & 0.56 & 0.46 \\
S15 & 61.46 & 0.11 & 131.86 & 0.36 & 0.46 & 0.48 & 0.40 \\
S16 & 60.97 & 0.11 & 131.16 & 0.35 & 0.45 & 0.48 & 0.39 \\
S17 & 50.84 & 0.09 & 110.34 & 0.29 & 0.38 & 0.40 & 0.33 \\
S18 & 48.86 & 0.08 & 103.68 & 0.28 & 0.32 & 0.38 & 0.31 \\
S19 & 48.28 & 0.09 & 102.58 & 0.28 & 0.33 & 0.38 & 0.31 \\
S20 & 51.65 & 0.09 & 110.17 & 0.30 & 0.37 & 0.41 & 0.33 \\
\hline Mean & $\mathbf{6 1 . 5}$ & $\mathbf{0 . 1 1}$ & $\mathbf{1 3 1 . 3 2}$ & $\mathbf{0 . 3 5}$ & $\mathbf{0 . 4 3}$ & $\mathbf{0 . 4 9}$ & $\mathbf{0 . 4 0}$
\end{tabular}

The contamination factor $\mathrm{CF}$ of each radionuclide in the soil samples was calculated and the pollution load index was estimated to ascertain the levels of pollution due to radionuclides. The contamination factor $(\mathrm{CF})$ was calculated using equation 7 as described by Hakanson (1980):

$$
C F=\frac{C_{i} n}{C_{B}}
$$

Where $\mathrm{C}_{\mathrm{i}} \mathrm{n}$ is the concentration of $\mathrm{i}_{\text {th }}$ radionuclide in the soil, and $C_{B}$ is the world average concentration of each radionuclide. $\mathrm{CB}$ was taken as $420 \mathrm{Bqkg}^{-1}, 45$ $\mathrm{Bqkg}^{-1}$ and $33 \mathrm{Bqkg}^{-1}$ for ${ }^{40} \mathrm{~K},{ }^{232} \mathrm{Th}$ and ${ }^{226} \mathrm{Ra}$, respectively (UNSCEAR, 2008). The result obtained is presented in Table 4 . The mean CF was 0.87 for ${ }^{228} \mathrm{Ra}$, 1.02 for ${ }^{232} \mathrm{Th}$, and 1.15 for ${ }^{40} \mathrm{~K}$. From the result, the soil is fairly polluted with ${ }^{232} \mathrm{Th}$ and ${ }^{40} \mathrm{~K}$. The pollution load index (PLI) was calculated using equation 8 described by Thomilson et al., (1980).

$P L I=\left(C F_{1} \times C F_{2} \times C F_{3} \times \ldots \ldots \ldots \times C F_{n}\right)^{1 / n}(8)$

Where $n$ is the number of radionuclides analyzed and $C F$ is the contamination factor of each radionuclide.

PLI $<1$ means no contamination; if PLI $<1$, means that only baseline levels of pollutants are present and PLI $>1$ means worsening of the quality of the soil sample (Thomilson et al., 1980).

The result obtained for PLI is presented in Table 5. The PLI of S1, S3, S7, S8, S11, S12, S14, S15, and S16 is higher than one, meaning that there is a drop in soil quality from the but safe in the other sites.
Table 5: Contamination factor (CF) and pollution level index (PLI) of the soil samples

\begin{tabular}{lllll}
\hline Sample & CF & CF & CF & PLI \\
ID & $\left({ }^{226} \mathrm{Ra}\right)$ & $\begin{array}{l}\left.{ }_{228} \mathrm{Ra}\right) \\
(40 \mathrm{~K})\end{array}$ & \\
\hline S1 & 1.02 & 1.09 & 1.43 & 1.17 \\
S2 & 0.44 & 0.77 & 1.55 & 0.82 \\
S3 & 1.45 & 1.46 & 1.62 & 1.51 \\
S4 & 0.62 & 0.92 & 1.39 & 0.93 \\
S5 & 0.87 & 1.03 & 1.07 & 0.98 \\
S6 & 0.38 & 1.07 & 1.48 & 0.9 \\
S7 & 1.40 & 1.49 & 1.14 & 1.35 \\
S8 & 1.08 & 1.17 & 0.93 & 1.1 \\
S9 & 0.45 & 0.81 & 1.17 & 0.76 \\
S10 & 0.56 & 0.91 & 0.91 & 0.78 \\
S11 & 0.94 & 1.37 & 1.25 & 1.17 \\
S12 & 1.05 & 1.01 & 1.02 & 1.05 \\
S13 & 1.35 & 0.80 & 0.79 & 0.95 \\
S14 & 0.67 & 1.30 & 1.38 & 1.1 \\
S15 & 1.17 & 0.90 & 1.10 & 1.05 \\
S16 & 1.07 & 0.97 & 1.04 & 1.04 \\
S17 & 0.92 & 0.86 & 0.76 & 0.85 \\
S18 & 0.46 & 0.89 & 0.96 & 0.73 \\
S19 & 0.61 & 0.80 & 0.95 & 0.92 \\
S20 & 0.87 & 0.77 & 0.98 & 0.87 \\
Mean & $\mathbf{0 . 8 7}$ & $\mathbf{1 . 0 2}$ & $\mathbf{1 . 1 5}$ & $\mathbf{1 . 0 6}$ \\
\hline
\end{tabular}

Conclusion: Measurement of NORMS in the soil around the Agbara Industrial area, Nigeria, was carried out. The mean concentrations of $232 \mathrm{Th}$ and $40 \mathrm{~K}$ were above the world average. Cancer risk is high in the area, indicating a high probability of developing cancer in the long term when a lifetime is spent in this area. The pollution level index indicated a drop in the quality of soil in the study.

\section{REFERENCES}

Agency for Toxic Substances and Disease Registry (ATSDR) (2014). Toxic Substances Portal- 
Thorium. Atlanta GA: Centers for Disease Control and Prevention

Al-Jundi, J; Al-Bataina, BA; Abu-Rukah, Y; Shehadeh, HM (2003). Natural radioactivity concentrations in soil samples along the Amman Aqaba Highway, Jordan. Radiat. Meas.36 (1): 555560

Attia, TE; Shendi, EH; Shehata, MA (2015). Assessment of natural and artificial radioactivity levels and radiation hazards and their relation to heavy metals in the industrial area of Port Said city, Egypt. Environ Sci. Pollute. Res. 22:3082-3097

Avwiri, GO; Olatubosun, SA (2014). Assessment of environmental radioactivity in selected dumpsites in Port Harcourt, Rivers State, Nigeria. Int. J. Sci. Technol. Res.3:263-269

Boukhenfouf, W; Boucenna, A (2011). The radioactivity measurements in soils and fertilizers using gamma spectrometry technique. J. Environ. Radioact. 102(4):336-339

Cevik, U; Damla, N; Koz, B; Kaya, S (2008). "Radiological characterization around the AfsinElbistan coal-fired power plant in Turkey. Energy Fuels. 22(1):428-432

El-Taher, S (2010). INAA and DNAA for uranium determination in geological samples from Egypt. Appl. Radiat. Isot, 68(6):1189-1192

Faisal, BMR; Haydar, MA; Ali, MI; Paul, D; Majumder, RK; Uddin, M.J (2014). Assessment of Natural Radioactivity and Associated Radiation Hazards in Topsoil of Savar Industrial Area, Dhaka, Bangladesh. J. Nucl. Particle Phys 4(4): 129-136.

Gbadamosi, MR; Banjoko, OO; Abudu, KA; Ogunbanjo, OO; Ogunneye, AL (2018). Radiometric evaluation of excessive lifetime cancer probability due to naturally occurring radionuclides in wastes dumpsites soils in Agbara, Southwest, Nigeria. J. Asso. Arab. Univ. Basic Appl. Sci. 24(1):315-324

Hakanson, L (1980). Ecological risk index for aquatic pollution control, a sedimentological approach. Water Res. 14: 975-1001

Ioannides, KG; Mertzimekis, TJ; Papachristodoulou, CA; Tzialla, CE (1997). Measurements of natural radioactivity in phosphate fertilizers. Sci. Tot. Environ. 196 (1) 63-67

International Atomic Energy Agency (IAEA) (1996) Radiation Safety. Regulation for the safe transport of radioactive material. IAEA Division of Public Information, 96-00725 IAEA/PI/A47E

International Commission on Radiological Protection (1991). Recommendation of the International Commission on radiological protection. ICRP publication 60, Annals of the ICRP; 21(1-3).

International Commission on Radiological Protection (2007). Publication 103. Annals of the ICRP; 37(24)

Recommendation of the International Commission on radiological protection Oxford: Pergamon Press. www.icrp.org/publication.asp?

Oladapo, OO; Oni, EA; Olawoyin, AA; Akerele, OO; Tijania, SA (2012). Assessment of natural radionuclides level in wasteland soils around Olusosun Dumpsite Lagos, Nigeria. J. Appl. Phys. 23:38-43

Ojekunle, ZO; Jinadu, OOE; Afolabi, TA; Taiwo AM (2018). Environmental Pollution and Related Hazards at Agbara Industrial Area, Ogun State. Sci. Rep. 8:6482

Sathyapriva, RS; Rao, DD; Prabhath, RK (2017). Choosing an appropriate method for measurement of ${ }^{232} \mathrm{Th}$ in environmental samples. Radiat. Prot. Environ. 40:90-4

Senthilkumar, RD; Narayanaswamy, R (2016). Assessment of radiological hazards in the industrial effluent disposed soil with statistical analyses. J. Radiat. Res. Appl. Sci. (9):449-456

Shen, Z; Zhang, Q; Cheng, W; Chen, Q (2019). Radioactivity of Five Typical General Industrial Solid Wastes and its Influence in Solid Waste Recycling. Minerals, 9, 168

Thomilson, DC; Wilson, DJ; Harris, CR; Jeffrey. DW (1980). Problem in heavy metals in estuaries and the formation of pollution index. Helgol. Wiss. Meeresunlter. 33(1-4): 566-575

Tufail, M; Akhtar, N; Waqas, M (2006). Measurement of terrestrial radiation for assessment of gamma dose from cultivated and barren saline soils of 
Faisalabad in Pakistan, Radiat. Meas.41 (4): 44451

Tzortzis, M; Svoukis, E; Tsertos, H (2004). A comprehensive study of natural gamma radioactivity levels and associated dose rates from surface soils in Cyprus. Radiat. Prot. Dosim. 109: 217-224

Ugbede, FO; Benson, ID (2018). Assessment of outdoor radiation levels and radiological health hazards in Emene Industrial Layout of Enugu State, Nigeria. Int. J. Phys. Sci. 13(20): 265-272

United Nations Scientific Committee on the Effects of Atomic Radiation (UNSCEAR, 1982). Ionizing radiation: sources and biological effects (New York: United Nations) E.82.IX.8

United State Environmental Protection Authority (2003). A Consolidated Emissions Modeling System for MOBILE6 and NONROAD, US Environmental Protection Agency, Office of Transportation and Air Quality, National Mobile Inventory Model (NMIM)
United Nations Scientific Committee on the Effect of Atomic Radiation (2008). Report to the general assembly. Annex B: exposures of the public and workers from various sources of radiation.

United Nations Scientific Committee on the Effects of Atomic Radiation (2000). Sources and Effects of Ionizing Radiation, UNSCEAR 2000 Report Vol.1 to the General Assembly, with scientific annexes, United Nations Sales Publication, United Nations, New York.

Zaim, N; Tugrul, AB; Atlas, H; Buyuk, B; Demir, E; Baydogan, N; Altınsoy, N (2016). Investigation of Natural Radioactivity of Surface Soil Samples in the Vicinity of Edirne-Turkey Special issue of the 2nd International Conference on Computational and Experimental Science and Engineering Acta Physica Polonica A. 130(1):64-67 